\title{
Stock Repurchases And False Signals
}

\author{
H. Kent Baker, (E-mail: kbaker@american.edu), American University
}

E. Theodore Veit, (E-mail: tveit@ rollins.edu), Rollins College

Gary E. Powell, Towson University

\begin{abstract}
Each year many firms repurchase shares of their common stock. Research evidence shows that when firms announce the repurchase of common stock, their share prices typically rise. Numerous studies attribute these increases to a signaling effect. But some firms that announce their intention of repurchasing shares of common stock either repurchase no shares at all or repurchase fewer shares than initially announced. Although the practice of firms intentionally announcing the repurchase of more shares than they expect to repurchase is illegal, the expected increase in share prices may give firms an incentive to make such false announcements.

This study surveys top financial executives to learn the extent that firms repurchase fewer shares than announced, identify the reasons for this activity, and learn how managers view this activity. We surveyed 642 firms that conducted common stock repurchases from January 1998 to September 1999. Based on 218 responses, we find that while managers are uncertain about the legality of this activity, they believe that the intentional repurchase of fewer shares than announced is unethical, sends a false signal to the market, and damages the firm's credibility with its stockholders. Managers also believe that firms repurchasing fewer shares than announced should publicly reveal both the reason for not repurchasing all shares and the amount by which the repurchase fell short of the firm's announced intentions. Despite these beliefs, managers report that repurchasing fewer shares than announced is a common practice.
\end{abstract}

\section{Introduction}

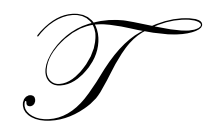

he repurchase of common shares by businesses is a common practice. For example, in 1996 a record 1,475 U.S. companies announced plans to buy back $\$ 177$ billion worth of common stock. ${ }^{1}$ Although the level of repurchase activity tends to be related to stock market performance, some repurchase activity continually takes place.

The finance literature has examined many aspects of repurchase activity. Some of the topics studied include why firms repurchase common stock, how stock prices react to repurchases and repurchase announcements, and how different repurchase methods (open market share repurchases, fixed-price tender offers, and Dutch-auction repurchases) affect the repurchase experience. Research has clearly shown that repurchase announcements lead to stock price increases. In fact, the market reaction to share repurchase announcements is often quite strong although the size of the reaction can depend on such factors as the form of the repurchase method and the reason for the repurchase. Theory suggests five major motives for firms to repurchase shares of their common stock: to signal positive inside information, to transfer wealth from creditors to stockholders, to change the firm's capital structure, to minimize stockholder taxes, and to fight a takeover attempt. ${ }^{2}$

If managers can raise the price of a firm's stock by signaling the existence of favorable inside information, do some managers send false signals to the market simply to generate an increase in the stock price? If so, does the company later pay a price for sending false signals through a loss of credibility? Existing literature sheds little light on these important ethical issues surrounding repurchase activities. Evidence exists that some firms announce

\footnotetext{
${ }^{1}$ The Wall Street Journal, February 10, 1997, pp. C1-C2.

${ }^{2}$ For a review of the literature on common stock repurchases, see Lease et al. (2000), pp. 153-177.
} 
repurchases but then do not follow through by repurchasing the number of shares announced (see Kracher and Johnson 1997, Kirch, BarNiv, and Zucca 1998, and Stephens and Weisbach, 1998). A study conducted by Birinyi Associates, Inc. (1996) found that firms made 1,155 repurchase announcements from 1984-1995, but only 997 firms completed the announced repurchases. Such activity may be explained by innocent factors such as a firm's changing financial situation or a change in a firm's need for treasury shares. Yet, some of this activity may be motivated by other intentions such as increasing the stock price by sending false signals to investors. Kracher and Johnson (1997) claim that some managers admit to having no intention of repurchasing the number of shares announced. Others such as Lee, Mikkelson, and Partch (1992) and Raad and Wu (1995) show that insiders tend to buy stock and reduce their selling of stock before their firms announce stock repurchases. Such trading activity may suggest that insiders want to take advantage of the price rise that usually accompanies stock repurchase announcements. Lee (1981) suggests that when a firm sends misleading signals, the market may respond by ignoring future communication from the firm. Christensen (2000) lists "creating management credibility" as one of four key components of any investor relations program if the firm's stock is to trade at a premium price.

Although some earlier studies have implied the possible existence of unethical behavior related to stock repurchase announcements, a lack of research exists into the explicit motivations of managers who fail to complete announced stock repurchases. The purpose of this study is to investigate the practice of repurchasing fewer shares than announced. In the current study we focus on the signaling motivation for share repurchase.

The remainder of the paper has the following organization. Section I presents relevant literature about stock repurchases and focuses on signaling and ethical issues. Section II presents our research questions and hypotheses. Section III describes the methodology used by the study and Section IV reports the empirical results. Section V reports the study limitations and Section VI contains conclusions.

\section{Literature Review}

According to signaling theory, companies use common stock repurchases to convey to the market positive information about the firm's future prospects. Those involved in developing signaling models related to stock repurchases include Vermaelen (1984), Ofer and Thakor (1987), Constantinides and Grundy (1989), and Hausch and Seward (1993). Vermaelen (1984) found evidence that permanent increases in stock prices follow repurchase. His findings suggest that the signaling hypothesis is the most likely explanation for the resulting abnormal returns. Vermaelen also developed a model showing a positive relationship between the strength of a repurchase signal through tender offers and three variables: the size of the offer premium, the percentage of shares the firm intends to repurchase, and the proportion of insider stock ownership.

Ofer and Thakor (1987) presented a model in which firms use both dividends and stock repurchases to signal financial markets. They show that firms prefer to signal the market using dividends when the difference between the market price of the stock and the stock's intrinsic value is small. Conversely, when this difference is large, firms use stock repurchases to signal the market. The reason for the preference for repurchases under these conditions is that repurchases contain more information.

Constantinides and Grundy (1989) developed a model in which firms raise funds through the issuance of debt and use the proceeds to finance investment. Any excess funds raised are used to repurchase stock. Share repurchases align manager's incentives with the market. If managers underestimate the value of the firm, the firm and its managers will lose more from the issuance of the debt than they will gain from the repurchase of the stock at a low price. If managers overestimate a firm's value, the firm will lose more from repurchasing the stock than it gains from issuing the debt. In the Constantinides and Grundy model, managers are banned from participating in stock repurchases. This is the primary difference between paying cash dividends and repurchasing stock.

The signaling model developed by Hausch and Steward (1993) makes the assumption that dividends are known with certainty while the value of a repurchase to investors is uncertain, particularly when a firm repurchases stock using the auction method. Given two high-quality companies, one with highly risk-averse managers and the other with less risk-averse managers, the two companies are likely to signal the firm's quality to stockholders 
differently. The more risk-averse managers are likely to distribute excess funds by means of a less-risky dividend while the less risk-averse managers are likely to distribute excess funds using a more risky stock repurchase.

Much empirical evidence shows that stock-repurchase announcements cause stock prices to rise. Masulis (1980) found that stocks generated an average 17 percent excess return during the two days following the announcement of a fixed-price repurchase. Dann (1981) reported a similar 15 percent excess return following the announcement of a fixed-price tender offer, although a 3 percent decline resulted after the expiration of the offer. Vermaelen (1981) also found a 15 percent excess return following the announcement of a fixed-price tender offer and a 3 percent decline after the expiration of the tender offer. Additionally, he found a 3 percent excess return around the announcement of open market repurchase programs.

Several survey studies also provided support for the signaling theory. Wansley, Lane and Sarkar (1989) found that the second most important reason cited by managers for repurchasing stock (out of 17 listed) was to signal investors that managers are confident about the company's future. Tsetsekos, Kaufman, and Gitman (1991) found that the third most important motive cited by managers for repurchasing stock was to "send a signal (information) to the market." Clearly, signaling is not simply a theoretical notion.

Although much has been written about repurchases, little research exists about possible legal and ethical concerns surrounding repurchases. Several studies report that some firms announce the repurchase of common stock without ever completing the repurchase (see Kracher and Johnson 1997, Kirch, BarNiv, and Zucca 1998, and Stephens and Weisbach, 1998). Netter and Mitchell (1989) report that following the stock market crash of 1987 many firms that announced stock repurchases did not follow through with the repurchases. They suggest that the motive underlying the repurchases was to increase the stock price. Because stock prices increased as a result of the announcement (signal), firms no longer needed to repurchase the shares. Netter and Mitchell did not address the possible implications of sending false signals. Kracher and Johnson (1997) report that some managers have admitted to having no intention of repurchasing all the shares they announced they would repurchase. They note that such deception of the investment community may achieve some short-term goals but that sending false signals can destroy the trust that is essential to the financial markets. The Securities and Exchange Commission (SEC) advises that the act of announcing the repurchase of a given number of shares when the intention is to repurchase fewer shares is a fraudulent act. ${ }^{3}$

Somewhat surprising are the results of research conducted by Kirch, BarNiv, and Zucca (1998). They find that the cumulative abnormal returns on the stocks of firms that follow through with their announced repurchases are lower than those on the stocks of firms that repurchase fewer than the announced shares. They conclude that this relationship may be explained by other firm-specific factors. Netter and Mitchell (1989) examined average abnormal returns from post-announcement day 2 to day 40 for firms that made open-market repurchase announcements following the 1987 stock market crash. They find no difference (5.37 percent versus 5.38 percent) in the average abnormal returns in NYSE/Amex exchange-listed firms that bought back stock from those that announced and did not buy back stock. However, the abnormal returns for OTC firms that announced but did not repurchase all announced shares were more than double (12.6 percent versus 5.47 percent) those of OTC firms that did follow through with the repurchase.

Several studies have addressed the issue of whether managers have violated insider trading rules by adding to their investment in their firm's stock with the knowledge of a pending repurchase program. Netter and Mitchell (1989) found no evidence of insiders attempting to benefit from inside information about pending stock repurchases. They attribute this to managers not wanting to violate insider trading laws. Yet, Raad and Wu (1995) found that, when insiders had net buying activity in their firm's stock, the excess return on the stock from a repurchase is larger and more significant than when insiders had net selling activity. Lee, Mikkelson, and Partch (1992) found that "prior to fixed price repurchase offers that do not follow takeover-related events, managers increase their buying and reduce their selling of their firm's stock." Based on these findings, and given the evidence that positive abnormal returns tend to result from stock repurchases, one might question the legality of such insider transactions. Another

\footnotetext{
${ }^{3}$ This information was provided by an attorney for SEC who cited rule 10b-5 which states, in part, that "It shall be unlawful for any person, directly or indirectly, by the use of any means...to make any untrue statement of a material fact or to omit to state a material fact necessary in order to make the statement made...not misleading..."
} 
question concerns the need to follow through with an announced repurchase. If managers buy stock with the intention of benefiting from a price rise that results from a stock repurchase announcement, is there a need to follow through with the repurchase after the managers have sold the stock? Conversely, Netter and Mitchell (1989) point out that if the goal of management is to bring the price of the firm's stock back up so it is no longer mispriced, no need exists to follow through with the repurchase once the stock price has risen.

\section{Research Questions and Hypotheses}

We designed the current study to test the following research questions and hypotheses, which are based on information presented in the literature review:

1. How prevalent is the practice of repurchasing fewer shares than the firm announced? We hypothesize that managers recognize that repurchasing fewer shares than a firm announced is a common practice.

2. Why do firms repurchase fewer shares than they initially announce? We hypothesize that firms repurchase fewer shares than they initially announce for a variety of reasons, including the original purpose of the repurchase no longer exists, the firm needed to use the funds elsewhere, the stock price rose.

3. Do managers believe that:

A. Failing to follow through with announced repurchases sends a false signal to the market?

B. Sending false signals to the market damages a firm's credibility with its stockholders? We hypothesize that the majority of responding managers agree with each of these statements.

We developed several additional hypotheses to be tested with the collected data. These hypotheses represent extensions of the previously listed hypotheses.

4. Do managers believe that the practice of repurchasing fewer shares than announced:
A. Is legal?
B. Is ethical?
C. Sends a false signal to the market?

We hypothesize that managers typically are unaware of the legality of this practice, but the majority believes this practice is unethical and sends a false signal to the market.

5. Do managers believe that firms should publicly announce:

A. The reason for not repurchasing all shares initially announce?

B. The amount by which a firm repurchases fewer shares than announced?

We hypothesize that, on average, managers agree with both statements.

6. Does the failure to follow through with an announced repurchase of shares of its common stock damage the firm's credibility with its stockholders? We hypothesize that managers, on average, believe that failing to follow through on repurchase announcements damages firm credibility because the firm is not keeping its word.

\section{Methodology}

The three subsections that follow describe the survey instrument used to collect information and important characteristics of the sample. 


\section{A. Survey Instrument}

The survey instrument was designed to gather background information about the respondents and to identify some specific repurchase activities of responding firms (see the Appendix). For example, we asked the respondents to give their opinions about certain repurchase activities, some of which may be unethical. In this study, we report the results that relate primarily to our research questions.

\section{B. Sample}

Birinyi Associates, Inc. provided a database consisting of two data sets: (1) U.S. corporations that announced the repurchase of common stock and (2) those firms that actually completed the purchase. We focused on the first data set. We believe that this database is superior to other sources for identifying buybacks, such as The Wall Street Journal (WSJ) Index. The Birinyi source is superior because it includes repurchase announcements and completions from a much wider variety of sources, including newspapers, journals, and financial sources including Bloomberg. Conversely, The WSJ Index relies on a single source.

We selected companies that announced repurchases between January 1998 and September 1999. We selected this period to help ensure that respondents were familiar with recent repurchase announcements. We verified the names and addresses of the top financial officers using the web site, Hoover's Online. After deleting some companies from the database because they no longer exist as independent firms, our final sample consisted of 642 firms whose shares trade on the NYSE, Amex, and NASDAQ.

We sent our initial mailing in mid-January 2000 and received 163 usable responses. Accompanying each survey was a cover letter asking for participation in the study and promising that individual responses would be kept confidential. We told the addressees that all responses would be reported in summary form only. We also told addressees that if they were not actively involved in their firm's most recent decision to repurchase common stock, they should forward the survey to someone in the firm who was actively involved. We sent a follow-up mailing to non-respondents in mid-February, which produced an additional 55 responses. Thus, we received a total of 218 usable responses, representing a $34 \%$ response rate ${ }^{4}$

Almost half of all respondents (47.4 percent) reported their current position as chief financial officer (CFO). Other common position titles of respondents included Vice President of Finance (12.1 percent), Vice President and CFO (10.2 percent) and Vice President and Treasurer (9.8 percent). Most of the remaining 20.5 percent of the respondents reported position titles of Treasurer, Assistant Treasurer, Director of Investments, or Senior Manager. When asked if they were actively involved in their firm's decision to repurchase stock, 197 (92.5 percent) responded affirmatively.

About $22 \%$ of respondents indicated their most recent stock repurchase was (or will be) completed in less than 3 months. Another 16\% indicated the repurchase would take from 3 to 6 months to complete while 27\% indicated it would take from 7 to 12 months. The total respondents indicating the repurchase will take one year or less is $65 \%$. Another $18 \%$ indicated it will take between one and 2 years and $17 \%$ indicated more than two years.

\section{Survey Results}

We present the survey results in two subsections. The first subsection focuses on the prevalence of repurchasing fewer shares than initially announced and the reasons underlying this practice. The second subsection reports the opinions of the respondents about practices used in repurchasing stock.

\footnotetext{
${ }^{4}$ Although our study included all methods of repurchase, the most common method used was open-market repurchase, which represented 89.8 percent of the 216 respondents to this question.
} 


\section{A. Buying Fewer Share than Announced}

Our first research question focused on how widespread the practice is of repurchasing fewer shares than previously announced. Specifically, we asked the respondents: "Based on your knowledge of current business practices, do firms frequently announce the repurchase of a specific number of common shares but intend to repurchase fewer shares?" Of the 202 managers who responded to this question, more than one-third (38.6 percent) indicated that this is a common business practice.

We were also interested in whether the respondents' firms had engaged in this practice. We asked: "Since 1995 has your firm announced the repurchase of shares of common stock and then purchased fewer shares than it announced it would repurchase?" Of the 216 managers responding, 28.7 percent indicated that their firms had done so. The literature offers several reasons why firms repurchase fewer shares than announced. Kirch, BarNiv, and Zucca (1998) suggest that firms repurchase fewer shares of common stock than announced either because of changes in a firm's internal or external environment or because of financial problems. Netter and Mitchell (1989) suggest that some firms stop the repurchase activity when the stock price rises to some desired level.

To determine why the respondents' firms had repurchased fewer shares than announced, we provided the survey participants with seven possible reasons and offered them an "other" response category. Respondents could indicate more than one reason. The 61 respondents who answered this question gave 92 responses. As Table 1 shows, the most common reason, given by 26.1 percent of the respondents, is that the firm is still in the midst of the repurchase program.

If we consider only the responses of firms that had time to complete their repurchases, the most common response is that the stock price rose making the repurchase of shares less attractive than initially anticipated. This response is consistent with Netter and Mitchell (1989) who suggest that some firms repurchase fewer shares than announced because the stock price rises to a level where management thinks it should be, based on other factors including signaling. The following three reasons, each receiving 12.0 percent of the responses, are tied for the next most important reason: (1) the firm ended the repurchase program after partially completing it, (2) the firm intended the original announcement as the maximum number of shares to be repurchased, ${ }^{5}$ and (3) the firm needed the funds initially allocated for the repurchase of shares elsewhere. A broad interpretation of the last reason is consistent with Kirch, BarNiv, and Zucca's (1998) notion that some firms repurchase fewer shares than announced because of financial problems. The two reasons given by the fewest respondents are that the original purpose for which the firm repurchased shares no longer exists ( 4.4 percent) and the firm withdrew the offer ( 3.3 percent). Slightly more than 14 percent of the respondents indicated an "other" reason. The most common "other" reason involved some form of reorganization such as a merger or acquisition.

\section{B. Opinions about Repurchase Practices}

Regardless of whether respondents were personally aware of instances in which firms repurchased fewer shares of stock than announced, we wanted to gather the respondents' views about several issues involving common stock repurchases. We asked the respondents to indicate their level of agreement or disagreement about six statements related to common stock repurchases. Respondents were to use a five-point scale where $-2=$ strongly disagree, $-1=$ disagree, $0=$ no opinion, $+1=$ agree, and $+2=$ strongly agree. For all statements, we used a $t$-test to determine if the mean response differed significantly from 0 (no opinion). We also separated the respondents into two groups. One group included firms indicating that the last time they announced a share repurchase they repurchased all shares announced (we call this group "All"). The second group consisted of firms that had repurchased fewer shares than announced (we call this group "Fewer"). We conducted chi-square tests to determine if there were significant differences between the responses of the two groups.

\footnotetext{
${ }^{5}$ Although 12 percent of the respondents said they intended the original announcement as a maximum, we checked to see if this is a common practice. We analyzed a sample of articles printed in the Wall Street Journal announcing the 1998 repurchase of common stock by companies participating in this study. This analysis showed that less than 5 percent of firms identified the announced shares as a maximum.
} 
Table 1 Reasons Firms Repurchased Fewer Shares than They Initially Announced

This table presents the reasons given by 61 respondents for their firms repurchasing fewer shares of common stock than initially announced since 1995. Because respondents could indicate more than one reason, the total number of reasons is 92.

\begin{tabular}{lr}
\hline Reason & $(\mathrm{n}=92)$ \\
\hline The firm is still in the midst of the repurchase program. & $26.1 \%$ \\
The stock price rose making the repurchase of shares less attractive than initially anticipated & 16.3 \\
The firm ended the repurchase program after partially completing it. & 12.0 \\
The firm intended the original announcement as the maximum number of shares to be purchased & 12.0 \\
The firm needed the funds initially allocated for the repurchase of shares elsewhere & 12.0 \\
The original purpose for which the firm repurchased shares no longer existed & 4.4 \\
The firm withdrew the offer & 3.3 \\
Other & 14.1 \\
Total & 100.2 \\
\hline
\end{tabular}

Percentages do not add to 100 due to rounding

One research question asked whether managers believe that announcing the repurchase of more shares than the firm intends to repurchase is a legal and ethical business practice? As Panel A-1 of Table 2 shows, when considering the total responses (see the column on the far right), the respondents were almost evenly split on their views about the legality of this business practice: 27.0 percent of respondents either disagreed or strongly disagreed and 27.5 percent either agreed or strongly agreed. Another 45.5 percent had no opinion, which implies that these respondents are not aware of the legal implications of intentionally announcing the repurchase of more shares than the company intends to repurchase. The mean response to this question is -0.07 , which is not statistically significant from zero at the 0.05 level $(\mathrm{t}=-0.868)$. This finding suggests that the respondents, on average, have no discernable opinion as to whether this activity is illegal or not. We used a chi-square test to see if the opinions of managers at firms repurchasing all announced shares differed from the managers of firms that repurchased fewer shares than announced. Because the calculated chi-square value is lower than the critical value, we conclude that there is no difference between the opinion of managers in the two groups.

As Panel A-2 of Table 2 shows, the majority of respondents (63.6 percent) either disagreed or strongly disagreed that the practice of repurchasing fewer shares than announced is ethical. About 18.2 percent had no opinion and another 18.2 percent agreed or strongly agreed that this practice is ethical. The average of -0.73 , which is statistically different from zero at the 0.01 level $(\mathrm{t}=-8.454)$, suggests that the average respondent believes that this practice is unethical. Once again, the calculated chi-square value was lower than the critical value leading us to conclude that there is no difference between the opinions of managers at firms repurchasing all announced shares and managers at firms that repurchased fewer shares than announced.

Panel A-3 indicates the responses to a question about whether failing to follow through with announced repurchases sends a false signal to the market. The data show that the vast majority of the respondents ( 77.6 percent) either agreed or strongly agreed with the statement. Only 8.6 percent of respondents either disagree or strongly disagree with this statement. The remaining 13.8 percent of respondents had no opinion. The weighted average response to this question was +1.10 , which differs significantly from zero at the 0.01 level $(t=15.789)$. This response indicates that the average respondent's opinion was between agreeing and strongly agreeing with the statement. These results are consistent with false signal arguments of Kracher and Johnson (1997). Although the respondents indicated general agreement that this activity sends a false signal to the market, the responses to an earlier question (see Panel A-1 of Table 2) suggest the same respondents are generally uncertain if this practice is illegal. Chi-square tests show there is no significant difference exists between the opinions of managers at firms repurchasing all announced shares and managers at firms repurchasing fewer than the announced shares.

We also asked whether managers believe that firms should publicly announce the reason for not repurchasing all shares announced and the amount by which the repurchase fell short of expectations. Panel B-1 of 
Table 2 shows that when asked if they agree that firms should announce to the public the reason for not repurchasing all announced shares, 34.4 percent either disagreed or strongly disagreed. Another 19.8 percent of respondents had no opinion. The remaining 45.9 percent of respondents either agreed or strongly agreed that firms should publicly announce the reason. The mean responses of +0.15 indicate that the average respondent showed some agreement that firms should publicly announce the reason for not repurchasing all the announced shares. The mean response differed significantly from zero at the 0.01 level $(t=1.814)$. The results of the chi-square test again lead us to conclude that there is no difference between the opinions of managers at firms repurchasing all announced shares and the managers at firms that repurchased fewer than the announced shares.

Panel B-2 of Table 2 shows that the majority of the respondents (55.7 percent) agreed or strongly agreed that firms should announce the amount by which the repurchase fell short of expectations. A total of 25.7 percent either strongly disagreed or disagreed with this statement while 18.7 percent had no opinion. The mean responses of +0.35 , differed significantly from zero at the 0.01 level $(t=4.195)$ suggesting that the average respondent agreed with the statement. The chi-square test again lead us to conclude that there is no difference between the opinions of managers at firms repurchasing all announced shares and the opinion of managers at firms that repurchased fewer than the announced shares.

Finally, Panel $\mathrm{C}$ of Table 2 shows the level of agreement of respondents to the following statement: "If a firm fails to follow through with an announced repurchase of shares of common stock, this typically damages the firm's credibility with its shareholders." While 23.5 percent of respondents disagreed or strongly disagreed with this statement and another 22.1 percent had no opinion, a majority of the respondents ( 54.5 percent) agreed or strongly agreed with the statement. The mean response was +0.39 , which differed from zero at the 0.01 level $(\mathrm{t}=5.549)$, suggesting that the average respondent agreed with this statement. This finding is consistent with Kracher and Johnson's (1997) argument that firms repurchasing fewer shares of stock than announced are sending false signals to the market and the firm will lose the trust of investors. The calculated chi-square value is below the critical value leading to the conclusion that there is no difference between the opinions of managers at firms repurchasing all announced shares and the opinion of managers at firms repurchasing fewer than the announced shares.

\section{Study Limitations}

The current study has several limitations. First, despite the high response rate for surveys of this type, the possibility of response bias remains. This is true even though we took the normal precautions to avoid response bias. We tested for non-response bias by conducting t-tests for differences in the mean value of certain firm characteristics for responding and non-responding firms. The characteristics tested included total assets, net sales, total debt to total capital, dividend yield, and price-to-book ratio. We included all firms used in our sample for which Compustat had data for 1997. We found no significant differences between the mean values for responding and nonresponding firms at the 0.05 level.

A second limitation is that we omitted a few firms from the sample because certain information was unavailable (e.g. the name of the top financial executive). This increases the possibility of response bias. Third, we could have asked more questions to gain even greater insight into the attitudes and opinions of financial executives. Given the tradeoff between survey length and the probability of realizing a high response rate, we chose to limit the number of questions.

\section{Conclusions and Implications}

In this study, we surveyed top financial managers of firms that announced the repurchase of shares of common stock between January 1998 and September 1999 to obtain their views about various practices and issues involving repurchases. Based on 218 responses, we found that many of the respondents perceived the practice of repurchasing fewer shares than initially announced as common. For those firms indicating they had completed their repurchase programs but had repurchased fewer shares than announced, the primary reason given was that the stock price rose making the repurchase of shares less attractive than initially anticipated. 
Table 2 Issues Involving Stock Repurchases

This table shows the responses to questions about the how managers view certain stock repurchase activities. Chi-square tests are used to test the null hypothesis that no difference exists between the proportion of responses to each issue involving stock repurchases for two groups: (1) All -- firms that repurchased all shares announced and (2) Fewer - firms that repurchased fewer shares than announced. None of the computed chi-squares tests is statistically significant at the 0.05 level with four degrees of freedom. Performing the chi-square results for question 3 shown in Panel A required collapsing the cells for strongly disagree (2) and disagree (-1) to avoid potential problems of inadequate cell size. Therefore, the chi-square test for A. 3 uses three degrees of freedom.

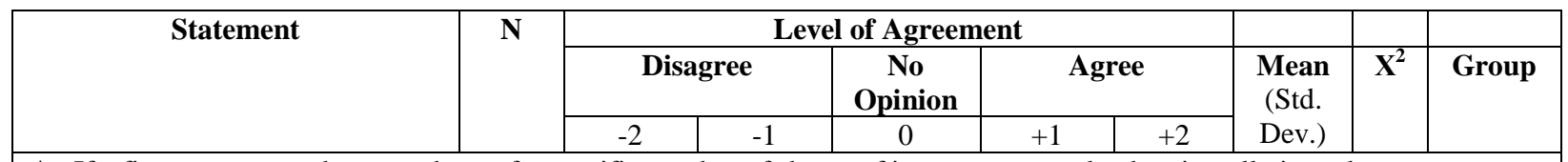

A. If a firm announces the repurchase of a specific number of shares of its common stock when it really intends to repurchase fewer shares, this:

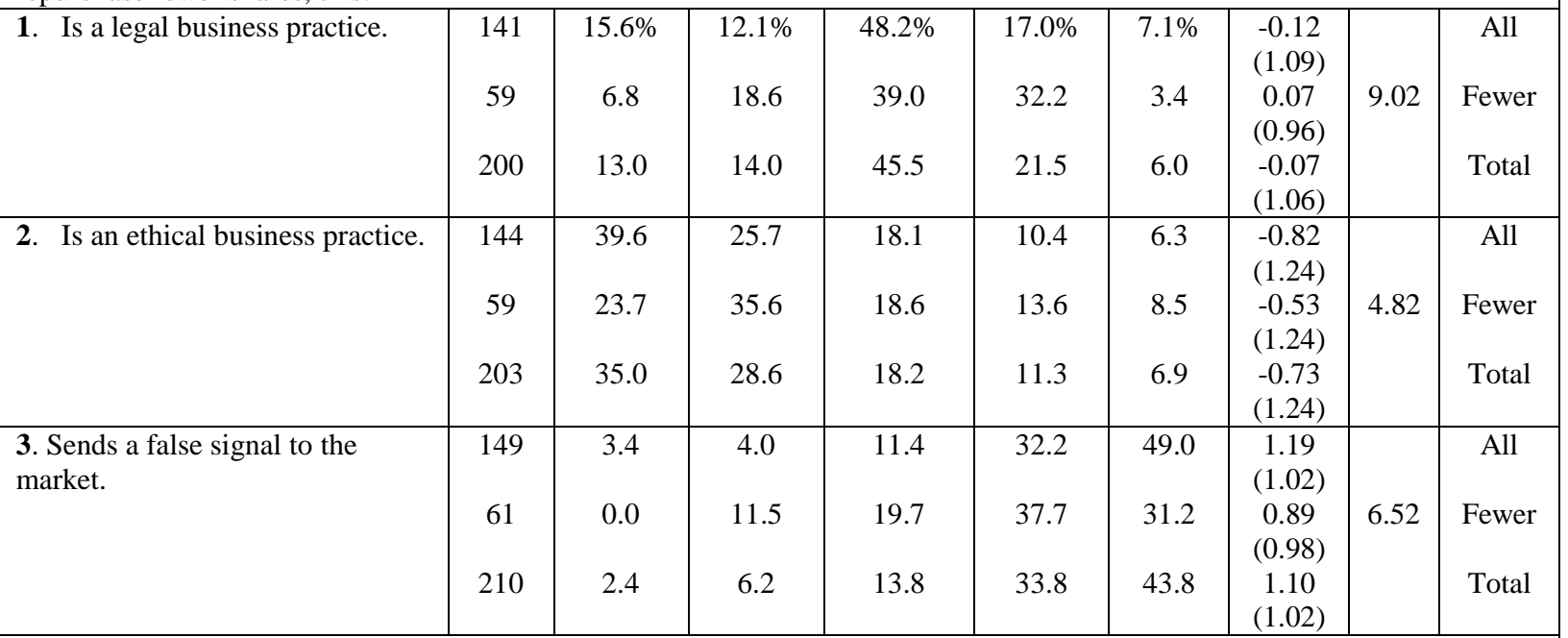

B. If a firm announces the repurchase of a specific number of shares of its common stock but does not repurchase all shares, the firm should publicly announce the:

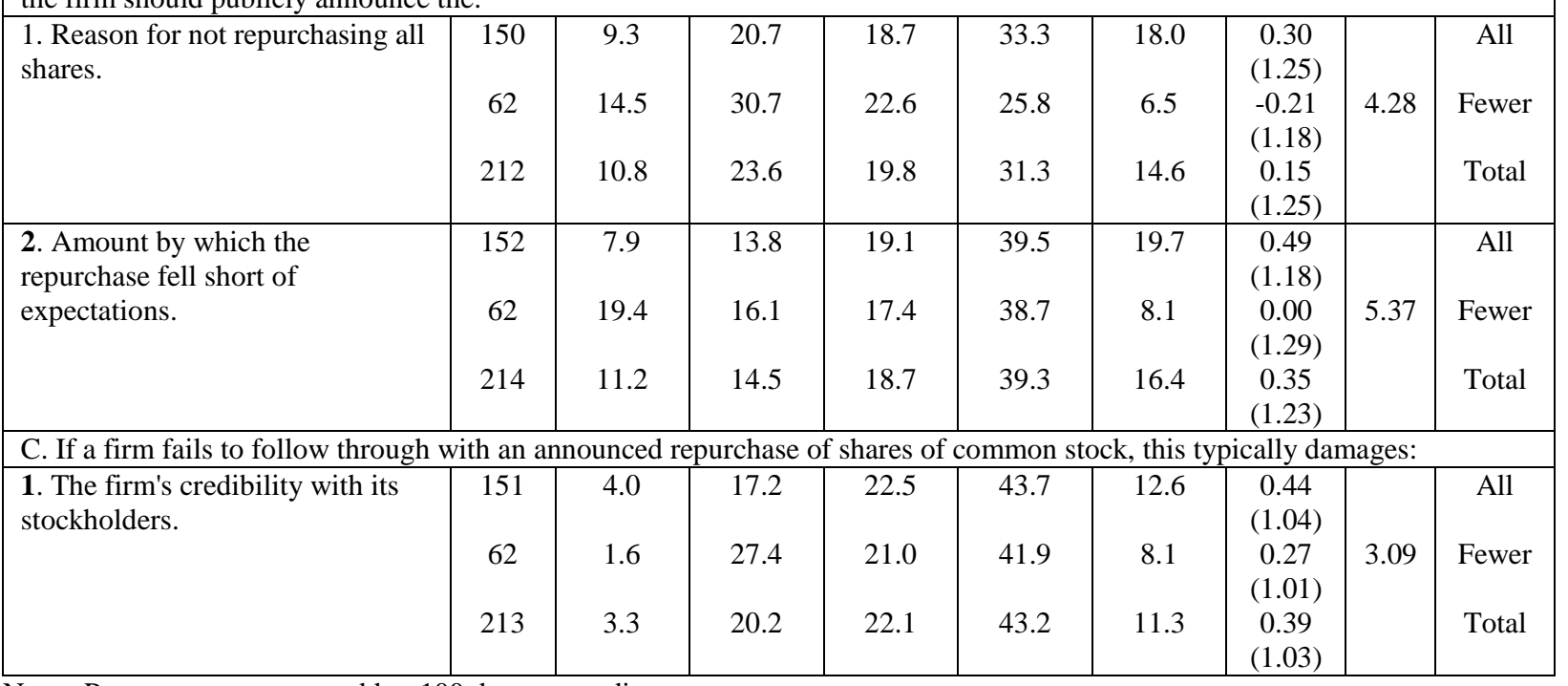

Note: Percentages may not add to 100 due to rounding. 
Table 3 Firm Characteristics: Responding Versus Non-Responding Firms

This table reports certain firm characteristics (total assets, net sales, total debt-to-total capital, dividend yield, and price-to-book ratio) for year-end 1997 for both the responding and non-responding firms. The first column lists the firm characteristic. The second and third columns report the value of the firm characteristic for responding and nonresponding firms, respectively, with the number of firms in parentheses below the value. The fourth column reports the t-value. To avoid potential size problems in conducting the t-tests, total assets and net sales are converted to natural logs.

\begin{tabular}{lccc}
\hline \multicolumn{1}{c}{ Firm Characteristic } & Responding Firms & $\begin{array}{c}\text { Non-Responding } \\
\text { Firms }\end{array}$ & t-value \\
\hline Total assets (in millions) & $\begin{array}{c}\$ 11,073.91 \\
(\mathrm{n}=185)\end{array}$ & $\begin{array}{c}\$ 10,745.09 \\
(\mathrm{n}=358)\end{array}$ & 0.592 \\
Net sales (in millions) & $\begin{array}{c}\$ 4,144.99 \\
(\mathrm{n}=184)\end{array}$ & $\begin{array}{c}\$ 5,093.94 \\
(\mathrm{n}=358)\end{array}$ & -0.147 \\
Total debt-to-total capital & $\begin{array}{c}38.17 \\
(\mathrm{n}=184)\end{array}$ & $\begin{array}{c}34.10 \\
(\mathrm{n}=356)\end{array}$ & 1.123 \\
Dividend yield & $\begin{array}{c}1.29 \\
(\mathrm{n}=182)\end{array}$ & $\begin{array}{c}1.06 \\
(\mathrm{n}=350)\end{array}$ \\
Price-to-book ratio & 4.13 & $\begin{array}{c}3.62 \\
(\mathrm{n}=349)\end{array}$ & 1.067 \\
\hline
\end{tabular}

In general, respondents were unsure about whether announcing the repurchase of a specific number of shares of common stock when a firm really intends to repurchase fewer shares is a legal business practice. However, the respondents generally agreed that such a practice is unethical and sends a false signal to the market. Despite these views, the practice of repurchasing fewer shares of stock than announced remains a fairly common practice. The respondents generally agree that failing to follow through with an announced repurchase of shares damages a firm's credibility with its stockholders. The respondents also generally agreed that firms should publicly announce the reason for not repurchasing all shares originally announced and the amount by which the repurchase fell short of expectations.

We believe the results of this study reveal an inconsistency in the opinions of managers. Managers do not want to lose credibility with stockholders. In this study, the responding managers generally agreed that not following through with announced repurchases causes firms to lose credibility with their stockholders. They also agreed that when firms fail to follow through with announced stock repurchases, this action sends a false signal to the market. Despite these beliefs, this practice continues. There was agreement that firms failing to complete an announced repurchase program should publicly announce why the repurchase fell short of expectations. However, this agreement was far weaker than agreement that firms failing to follow through with announced repurchases can cause firms to lose credibility with their stockholders.

Based on the study's findings, we believe that managers need to recognize that a problem exists. The primary problem is that some managers may be giving false signals to the market by announcing stock repurchase programs on which the firm does not follow through. Whether this act is intentional or unintentional is less important than the fact that sending false signals to the market can have negative consequences. Therefore, firms announcing share repurchases should have every intention of carrying through with the repurchase. If conditions warrant a change in the repurchase program, managers should publicly announce both the reason for the change and the nature of the change (how will it affect the number of shares repurchased). In our view, managers should address this problem before regulatory agencies create rules and regulations that restrict current freedoms. 
The authors want to thank Sumeet Chawla, Dennis P. Newman, Todd S. Rich, and Matthew K. Sullivan for providing research assistance. American University and the Kogod School of Business provided research support.

\section{References}

1. $\quad$ Birinyi Associates, Inc., 1996, The Buyback Paradox, Greenwich, CT.

2. Christensen, Jeff, 2000, "Speaking of Stock Value," Oil \& Gas Investor 20: 2, 51-53.

3. Constantinides, George M. and Bruce D. Grundy, 1989, "Optimal Investment with Stock Repurchase and Financing as Signals." Review of Financial Studies 2:4, 445-465.

4. "Dann, Larry Y., 1981, "Common Stock Repurchases: An Analysis of Returns to Bondholders and Stockholders," Journal of Financial Economics 9:2 (June) 113-139.

5. Hausch, Donald B., and James K. Seward, 1993, "Signaling with Dividends and Share Repurchases: A Choice between Deterministic and Stochastic Cash Disbursements," Review of Financial Studies 6:1, 121154.

6. Kirch, David P., Ran BarNiv, and Linda J. Zucca, 1998, "Investment Strategies Based on Completion of Open Market Repurchase Programs," Journal of Financial Statement Analysis," 3:2 (winter), 5-14.

7. Kracher, Beverly and Robert R. Johnson, 1997, "Repurchase Announcements, Lies and False Signals," Journal of Business Ethics 16:15 (November), 1677-1685.

8. Lease, Ronald C., Kose John, Avner Kalay, Uri Loewenstein, and Oded H. Sarig, 2000, Dividend Policy: Its Impact on Firm Value, Boston, MA, Harvard Business School Press.

9. Lee, D. Scott, Wayne H. Mikkelson, and M. Megan Partch, 1992, "Managers' Trading Around Stock Repurchases," Journal of Finance, 47:5 (December), 1947-1962.

10. Lee, F.A., 1981, Public Disclosure of Corporate Earnings Forecasts, New York: The Conference Board, Inc.

11. Masulis, Ronald W., 1980, "Stock Repurchases by Tender Offer: An Analysis of the Causes of Common Stock Price Changes," Journal of Finance 35:2 (May), 305-321.

12. Netter, Jeffry M. and Mark L. Mitchell, 1989, "Stock Repurchase Announcements and Insider Transactions After the October 1987 Stock Market Crash," Financial Management, 18:3 (Autumn), 84-96.

13. Ofer, Aharon R. and Anjan V. Thakor, 1987, "A Theory of Stock Price Responses to Alternative Corporate Cash Disbursement Methods: Stock Repurchases and Dividends," Journal of Finance 42:2 (June), 365-395.

14. Raad, Elias and H. K. Wu, 1995, "Insider Trading Effects on Stock Returns Around Open-Market Stock Repurchase Announcements: An Empirical Study,” Journal of Financial Research 18:1 (Spring), 45-57.

15. Rule 10b-5 of the Security and Exchange Commission's Rules of Practice, Securities and Exchange Commission, Washington, D.C.

16. Securities and Exchange Commission, 2000. Telephone conversation between E. Theodore Veit and an attorney for the SEC on Thursday June 15, 2000, and follow-up emails on June 18, 2000, relative to what constitutes fraudulent activities.

17. Stephens, Clifford P. and Michael S. Weisbach, 1998, "Actual Share Reacquisitions in Open-Market Repurchase Programs,” Journal of Finance, 53:1 (February), 313-333.

18. Tsetsekos, George P., Daniel J. Kaufman, Lawrence J Gitman, 1991, "A Survey of Stock Repurchase Motivations and Practices of Major U.S. Corporations," Journal of Applied Business Research, 7:3 (summer) 15-20.

19. Vermaelen, Theo, 1981, "Common Stock Repurchases and Market Signalling: An Empirical Study," Journal of Financial Economics 9:2 (June), 139-84.

20. Vermaelen, Theo, 1984, "Repurchase Tender Offers, Signaling, and Managerial Incentives," Journal of Financial and Quantitative Analysis 19:2 (June) 163-181.

21. Wansley, James W., William R. Lane, and Salil Sarkar, 1989, "Managements' View on Share Repurchase and Tender Offer Premiums," Financial Management, 18:3 (autumn), 97-110. 


\section{Appendix}

\section{Common Stock Repurchase Survey}

\section{Reasons for repurchasing common stock}

Directions: Circle the number corresponding to the importance of each reason for your firm's most recent common stock repurchase.

\begin{tabular}{cccc}
\multicolumn{3}{c}{ Level of Importance } \\
\hline None & Low & Moderate & High \\
0 & 1 & 2 &
\end{tabular}

Circle One

Level of Importance None High

\section{My firm most recently repurchased shares of its common stock to:}

1. Best use excess cash.

2. Increase the stock price.

3. Add value to shareholders.

4. Increase earnings per share.

5. Acquire stock at a bargain price.

6. Obtain stock for possible acquisitions.

7. Remove an overhanging block of stock.

8. Change the capital structure of the firm.

9. Serve as a substitute for a cash dividend.

10. Change the ownership structure of the firm.

11. Provide stock for dividend reinvestment plans.

12. Provide stock for conversion of other securities.

13. Serve as part of a general corporate restructuring.

14. use the stock as part of a takeover defense strategy.

15. Reduce the cost of servicing small odd lot shareholdings.

16. Provide a tax-efficient way to distribute funds to shareholders.

17. Gain publicity through press announcements about the repurchase.

18. Convey positive information possessed by management to the market.

19. Reduce future total dividend payments by reducing the number of shares outstanding.

20. Provide stock for employee compensation needs such as bonus and stock option plans.

21. Other (specify)

$\begin{array}{llll}0 & 1 & 2 & 3 \\ 0 & 1 & 2 & 3 \\ 0 & 1 & 2 & 3 \\ 0 & 1 & 2 & 3 \\ 0 & 1 & 2 & 3 \\ 0 & 1 & 2 & 3 \\ 0 & 1 & 2 & 3 \\ 0 & 1 & 2 & 3 \\ 0 & 1 & 2 & 3 \\ 0 & 1 & 2 & 3 \\ 0 & 1 & 2 & 3 \\ 0 & 1 & 2 & 3 \\ 0 & 1 & 2 & 3 \\ 0 & 1 & 2 & 3 \\ 0 & 1 & 2 & 3 \\ 0 & 1 & 2 & 3 \\ 0 & 1 & 2 & 3 \\ 0 & 1 & 2 & 3 \\ 0 & 1 & 2 & 3 \\ 0 & 1 & 2 & 3 \\ 0 & 1 & 2 & 3\end{array}$

\section{Background Information}

Directions: Place a check mark $(\checkmark)$ next to your answer. Check only one response for each question, except Question 8. If you have no opinion or do not know the answer, please skip the question.

1. What was the most important circumstance that led to your firm's most recent common stock repurchase?

$\square$ Low (undervalued) stock price

$\square$ Lack of profitable investment opportunities

$\square$ Need for treasury stock

$\square$ Other (specify)

2. What was the primary method used by your firm to accomplish its most recent common stock repurchase?

Open-market repurchase

Targeted block repurchase $\square$ Fixed-price tender offer $\quad \square$ Dutch-auction tender offer

$\square$ Other (specify) 
3. What was the primary source of funds used by your firm to finance its most recent common stock repurchase?

$\begin{array}{lll}\square \text { Available cash balances } & \square \text { New short-term debt } & \square \text { New long-term debt } \\ \square \text { New preferred stock } & \square \text { Other (specify) }\end{array}$

4. Has your firm completed its most recent common stock repurchase?

$\square$ Yes $\square$ No

5. How long did it take your firm to complete the most recent common stock repurchase once initially announced?

(If your firm has not completed its most recent common stock repurchase, how long do you estimate it will take?)
口Less than 3 months
$\square 3$ to 6 months
$\square 7$ to 12 months
$\square 13$ to 18 months
$\square 19$ to 24 months
$\square$ More than 24 months

6. Based on your knowledge of current business practices, do firms frequently announce the repurchase of a specific number of shares of their common stock but intend to repurchase fewer shares?

$\square$ Yes $\quad \square$ No

7. Since 1995 has your firm announced the repurchase of shares of common stock and then repurchased fewer shares than it announced it would repurchase?

$\square$ Yes $\quad \square$ No

8. If you answered "yes" to Question 7, why did your firm repurchase fewer shares of common stock than it announced it would repurchase? Check all that apply.

$\square$ The firm withdrew the offer.

$\square$ The firm is still in the midst of the repurchase program.

$\square$ The firm ended the repurchase program after partially completing it.

$\square$ The original purpose for which the firm repurchased shares no longer existed.

$\square$ The firm needed the funds initially allocated for the repurchase of shares elsewhere.

$\square$ The stock price rose making the repurchase of shares less attractive than initially anticipated.

$\square$ The firm intended the original announcement as the maximum number of shares to be repurchased.

$\square$ Other (specify)

9. Were you actively involved in your firm's most recent decision to repurchase common stock?

$\square$ Yes $\quad \square$ No

10. What is your current position or title? 


\section{Issues Involving Common Stock Repurchases}

Directions: Circle the number corresponding to your level of agreement or disagreement with each statement about common stock repurchases in general.

\begin{tabular}{|c|c|c|c|c|c|}
\hline \multicolumn{5}{|c|}{ Level of Agreement } & \multirow{3}{*}{$\frac{\text { Circle One }}{\text { Level of Agreement }}$} \\
\hline Strongly & & No & & Strongly & \\
\hline Disagree & Disagree & Opinion & Agree & Agree & \\
\hline-2 & -1 & 0 & +1 & +2 & Disagree Agree \\
\hline
\end{tabular}

1. The announcement of a common stock repurchase typically:

A. leads to an increase in the firm's stock price.

$\begin{array}{lllll}-2 & -1 & 0 & +1 & +2\end{array}$

B. leads to an increase in the firm's cost of equity capital.

$\begin{array}{lllll}-2 & -1 & 0 & +1 & +2\end{array}$

C. leads to a decrease in a stock's liquidity as measured by an increase in the

$\begin{array}{lllll}-2 & -1 & 0 & +1 & +2\end{array}$

bid-ask spread.

D. benefits participating stockholders more than nonparticipating stockholders.

$\begin{array}{lllll}-2 & -1 & 0 & +1 & +2\end{array}$

2. If a firm announces the repurchase of a specific number of shares of its common stock but does not repurchase all shares, the firm should publicly announce the:
A. reason for not repurchasing all shares.
B. amount by which the repurchase fell short of expectations.
$\begin{array}{lllll}-2 & -1 & 0 & +1 & +2\end{array}$
$\begin{array}{lllll}-2 & -1 & 0 & +1 & +2\end{array}$

3. If a firm announces the repurchase of a specific number of shares of its common stock when it really intends to repurchase fewer shares, this:
A. is a legal business practice.
B. is an ethical business practice
$\begin{array}{lllll}-2 & -1 & 0 & +1 & +2\end{array}$
C. sends a false signal to the market.
$\begin{array}{lllll}-2 & -1 & 0 & +1 & +2\end{array}$
$\begin{array}{lllll}-2 & -1 & 0 & +1 & +2\end{array}$

4. If a firm fails to follow through with an announced repurchase of shares

of its common stock, this typically damages the firm's credibility with its stockholders. $\begin{array}{llllll}-2 & -1 & 0 & +1 & +2\end{array}$

5. A firm should typically distribute cash to stockholders above the regular cash dividend by repurchasing its shares of common stock instead of by paying an additional cash dividend. $\quad-2 \quad-1 \quad 0 \quad+1+2$

If you want a summary of the findings, please indicate your e-mail address:

Please check to see that you answered each question. Thank you for your help.

Company code 